\title{
A study on Women Empowerment Self Help Group with reference in Perambalur District
}

\author{
${ }^{1}$ Dr. D. Kalaiselvan, ${ }^{2}$ Mr.T.Jeyaraj \\ ${ }^{1}$ Associate Professor in Commerce, Srinivasan College of Arts and Science, Perambalur- \\ ${ }^{2}$ Associate Professor in Commerce, Srinivasan College of Arts and Science, Perambalur-
}

\begin{abstract}
Women empowerment is a process in which women challenge the existing norms and culture, to effectively promote their well being. The participation of women in Self Help Groups (SHGs) made a significant impact on their empowerment both in social and economical aspects This study addresses women empowerment through self help groups in Perambalur district of Tamilnadu. The information required for the study has been collected from both the primary and secondary sources A multistage random sampling method has been followed. Average and percentage analysis was carried out to draw meaningful interpretation of the results. Garret ranking technique was used to find the reasons for joining the Self help group. Factor analysis was used to measure the determine the relationship between the observed variables The results of the study revealed that the SHGs have had greater impact on both economic and social aspects of the beneficiaries.
\end{abstract}

Key words: Woman empowerment, SHG, Perambalur, Tamilnadu

\section{Introduction}

India lives in her 6, 38,345 villages with 24 crore poor engaged in micro enterprises. As per the Government of India's Ministry of Micro, Small and Medium Enterprises (MSES) Annual report 2008-2009, there are 133.68 lakhs (in number) micro enterprises in India. Poverty in India is widespread with the nation estimated to have a third of the world's poor. The credit needs and other financial services are provided to the rural masses in general and to the poor in particular through the rural financial markets comprising an unorganized sector consisting of commission agents, moneylenders, landlords, etc., and an organized sector consisting of pyramid type cooperative credit institution - broadly classified into urban credit cooperatives and rural credit cooperatives.

In order to enlarge the flow of credit to the hard-core poor, NABARD launched a scheme of organizing them in self-help groups (SHGs) and linking the SHGs with banks, in 1992. The scheme is broadly on the pattern devised by Bangladesh Grameen Bank. Under the scheme, poor, preferably the women are organized in SHGs and banks financing these SHGs for on lending to poor are eligible for concessional refinance from NABARD.

There are three distinct modes to route the credit to micro enterprises. While under the first mode, banks lend directly to the SHGs for lending to micro entrepreneurs. Under the second mode, banks provide loans to the NGOs for on lending to the SHGs and ultimately to micro entrepreneurs. Under the third mode, banks extend credit to the SHGs with the NGO as facilitator. Though the SHGs were started in 1997 in Tamil $\mathrm{Nadu}$, the concept penetrated down only in recent years. Now there is a greater amount of socio-economic emancipation among the members of the SHGs. Hence there is a need for evaluating the social and economic impact of the SHGs on their members.

Among the various districts of Tamil Nadu, Perambalur District occupies a predominant position in the starting of SHGs. In this district the urban centers have more rural bias and the economic activities are more agro-based. Hence the SHGs have been formed for meeting the needs of industrial and agricultural activities. As on November 2008, there were 3.78 lakhs SHGs in Tamil Nadu with a membership of 60.63 lakhs. And in Perambalur District there were 12060 SHGs with a membership of near by 1.60 lakhs.

The present study deals with the SHGs formed in Perambalur district. The empirical findings of this study would pave the way for taking certain policy decisions for strengthening the SHGs and hence the study has been undertaken in Perambalur district.

\section{Statement Of The Problem}

Poverty and unemployment are the twin problems faced by the developing countries. According to the Planning Commission more than one third of India's total population i.e. 320 million live below the poverty line. In India, the financial institutions have not been able to reach the poor households particularly women in the unorganized sector. Structural rigidities and overheads led to high cost in advancing small loans.

Experience in implementing different anti-poverty and other welfare programmes has shown that the key to success lies in starting appropriate community-based organisations with participation at the grass-root level. 
Moreover, the group approach may be one of the effective ways to reduce the difficulties of small businessmen and agriculturists. Motivating individual farmers, artisans and entrepreneurs to form small groups to pool their resources to handle selected operations may lead to a great success.

Peoples' participation in credit delivery and recovery and linking of formal credit institutions to borrowers through the SHGs have been recognized as a supplementary mechanism for providing credit support to the rural poor. The SHGs are informal groups formed on a voluntary basis, for providing the necessary support to their members for their social and economic emancipation.

These groups are distinct from co-operative societies, mainly in terms of their size, homogeneity and functions. Non-Governmental Organisations play an important role in preparing the members by changing their attitude to participate in-group activities.

The NABARD is a pioneer in conceptualising and implementing the concept of the SHGs through the pilot project of linking SHGs with banks. In 1992 the project was commenced throughout the country through a set of well-defined guidelines with special reference to the objectives, criteria for selection of SHGs, size of group, assessment of credit needs, rate of interest, repayment period and security. Efforts were also made by NABARD to popularise the project among bankers and the NGOs by organising a series of workshops and seminars at different levels. The response from banks and the NGOs was encouraging and positive.

The distinguishing feature of the SHGs is creating social and economic awareness among the members. The social awareness enables the members to lead their life in a sound hygienic environment and pursue a better living. The woman members involve themselves more in taking decisions regarding the education of their children, the investment of the family, managing the economic assets of the family and bringing up cohesion among the members of the family and others for a better living.

On the economic point of view both men and women work shoulder to shoulder to increase the income of the family. Every member of the SHGs has felt the need for more involvement in economic activities. The spirit for social and economic upliftment of members is the significant contribution of each and every SHG.

There is a general tendency to consider the SHGs as a panacea for all the ills of the rural community. This is evident from mushroom growth of self help group in the states and also in Perambaluri District. In Perambalur District, in the year 1998, the number of SHGs formed was 621. But in the year 2008 it was 10,773. In many cases it has been a blind replication of success models without considering the intricacies involved in group formation and sustainability. Hence the present study is undertaken to study the performance of SHG in Perambalur district. Further an attempt is also made to evaluate the social and economic benefits accruing to the members of the SHGs.

\section{Objectives Of The Study}

The objectives of the present study are as follows:

* To analyse the genesis and development of SHGs in Perambalur Distirct

* To evaluate the performance of the sample SHGs in Perambalur District selected for the study

* To anlayse the changes in the social conditions of the members of the self-help groups

* To measure the impact of the SHGs on the economic development of the members

* To analyse the attitude of the members of the SHGs towards economic impact, social impact, psychological impact and political impact

* To offer suggestions to improve the working of the SHGs.

\section{Scope Of The Study}

The present study attempts to examine the socio-economic impact of the SHGs on the beneficiaries. It examines how far the programme has helped in raising the incomes and levels of living of the rural poor women and in enabling them to cross the poverty line. The present study is from the standpoint of the SHGs and their members.

\section{Hypotheses}

The hypotheses framed are: there is no significant difference in the performance of SHGs and tenure of existence, literacy level of the leader and size of membership of the groups; there is no significant difference in the social and economic condition of the members before joining SHGs and afterwards; and there is no significant difference in the perception scores of the different groups of members and social factors and the attitude of the members.

\section{Methodology}

The present study is based on both primary and secondary data. The primary data were collected through two interview schedule, one for SHGs and another for SHG's members. The secondary data were collected from books, journals, websites and records of Mahalir Thittam Office, Perambalur. The data were 
collected from 150 Self Help Groups and 570 members through interview schedule. Average and percentage analysis was carried out to draw meaningful interpretation of the results. Garret ranking technique was used to find the reasons for joining the Self help group. Factor analysis was used to measure the determine the relationship between the observed variables

\section{Findings}

An attempt is made to analyse the performance of SHGs in Perambalur district and social and economic impact on members of SHGs. In order to measure the performance of SHGs in perambalur district, various factors such as homogeneity, regularity in conducting the meetings, regularity in attendance, role of NGOs in meetings, repayment performance, decision on financial transactions, utilisation of common fund, increased rate of savings, awareness of rules and regulations, and maintenance of accounts have been taken into account.

It is found that $63 \%$ of SHGs conducted meeting once in a week. There was more NGO participation. The performance of repayment is better in all groups. $80 \%$ of the loan is utilised for productive purposes. The savings performances of SHGs are up to the mark. All the members of SHGs availed training facilities provided by the Mahalir Thittam. The books of accounts are properly maintained. Further it is found that there is significant difference in performance scores among the different groups in conduct of meeting, regularity in attendance, participation of NGOs in meeting, repayment performance, decision on financial transactions, utilisation of common fund and training. But there is no significant difference in the performance scores among the different groups obtained indicators such as homogeneity, share of production loan to total loan, increased rate savings, awareness of rules and regulations and maintenance of books of accounts.

It is also found that there is no influence of the tenure of existence of the SHGs on performance. But the literacy level of leader and the size of the membership of the SHGs influence the performance of SHGs. To assess the social impact of the SHGs on its members, first the socio - economic factors of the members are studied. Then social issues like self confidence, awareness of social evils, behavioural changes, change in education level, access to amenities and political participation also discussed. It is found that association with SHGs encompasses a large cross section of people with self - confidence. Association with SHGs increases the helping tendency.

The membership in SHGs gave importance to woman in family decision. It is also found that there is a significant shift in the level of communication, which might be due to association with the SHGs. SHGs create awareness among members on the social evils. The study also shows that there is a positive impact of SHGs on members in resisting social evils. It is interesting to note that all the members of SHGs avail all the social living amenities in the urban and rural areas to the fullest level possible. It is inferred that $96.1 \%$ of members have shown their interest in contesting elections after joining the SHGs.

The economic impact of the SHGs on the members have been analysed in terms of their level of savings, amount of borrowings, creation of assets, employment generation, income generation, poverty level and expenditure pattern. It is found that after joining SHGs, the awareness level of savings increased. There is a paradigm shift from loans borrowed for consumption purposes to productive purposes after association with SHGs. It is found that the SHG programmes have positive effect on alleviation of poverty. The consumption expenditure of the members has increased after becoming members of SHGs. The Composite Index of standard of living shows that the impact of micro credit encompassing economic as well as social aspects was relatively more pronounced on the social aspects than on the economic aspects.

The perception of the sample respondents regarding the economical impact, social impact, psychological impact and political impact shaped by the SHGs has been analysed with the help of a scaling technique. It is found that the perception of the sample members on social impact occupies first place followed by psychological impact, economical impact and political impact. It is also found that the four categories of impact are equally important. Chi- square test was used to explore relationship between personal variables and the perception of impact. It is found that the age, occupational pattern, marital status and community influences the perception of members on the nature of the impact. On the other hand, the level of literacy had no influence on perception of members of the impact of the SHGs.

\section{Suggestions}

Based on the above findings, the following suggestions are made.

- 144 (75.8\%) sample SHGs are purely depending upon the NGOs in financial decision making process. In the inception period, the NGOs are forming and giving necessary training to SHGs. After some period, they have to give the freedom to think and work especially in decision making process. The financial decisions are to be taken by all the members unanimously. Hence, it is suggested that the necessary skills with regard to financial decision making may be inculcated to the members of SHGs. In this regard, a financial literacy and credit counseling centre may be opened in every district with suitable financial experts, bank officials etc. 
This credit counseling centre may give the suitable training to all the members of SHGs in the field of financial management.

- The study shows that $62.1 \%$ of SHGs are formed in rural panchayats, $18.11 \%$ in town panchayats, $11.24 \%$ in municipal areas and only $18.5 \%$ in corporation areas. As the SHGs are playing a crucial role in alleviation of poverty, steps may be taken on war footing basis to form more number of SHGs not only in rural but also in municipal and corporation areas in Tirunelveli District. In this regard, the state Government may consider giving preference to uncovered areas for promoting the SHGs.

- Mahalir Thittam Office, in Perambalur has arranged more number of training for the members of SHGs to start their own economic activities. The training was given only on the conventional or traditional business activities. Apart from this, only half of the respondents have received training and orientation for capacity building. These training programmes were attended by some members only. Overall, the training programmes have not been useful to the participants. It is suggested that training on innovative economic activities by using the resources in and around the district may be given to the SHGs members. The training in the areas such as vermicelli making, beautician training, training on bakery unit may also be given. For this purpose, Entrepreneurship development cell in the district, resource persons from small scale sectors, private ventures may also be properly used. And chances should be given to all members by rotation to attend the training programmes. In this way the SHGs can able to know the innovative ideas for income generating activities and all the members can develop their skill. Only 8 groups have recorded as poor repayment performance of loan in the district. It is suggested that incentives may be given for prompt repayment. This will catch the attention of the groups to repay the loan. Further, suitable advice may also be given the members of SHGs for prompt repayment of loan.

- Among the sample only $35.78 \%$ (68) of SHGs are increased their savings less than $20 \%$. Hence, it is suggested that motivational campaign may be conducted for inculcating saving habit in the minds of the members. The campaign should give the exposure of savings, its future benefits, how the savings of members are utilised for rotation among the members, how the amount of groups' savings form a base for getting government sponsored scheme for income generating activities and the benefits to the individual member.

- It is found that among the sample $40(21.05 \%)$ SHGs are faced the problem of delay in sanctioning the loan. It is suggested that the bank should visit SHGs and grade them based on their quality. The grading system and format is already approved by NABARD. If needed, banks can outsource the task of grading the SHGs to third party to expedite the sanctioning of loan. Further, the loan applications of SHGs should not be delayed beyond 15 days. Banks can fix a day for transactions of SHGs. The formalities while opening the SHG accounts in banks and while advancing loan to them should be minimum and procedures should be simplified. There should be uniform format for account opening and loan applications across banks. It is also suggested that necessary instructions may be given to the authorities and bank officials to avoid the delay in sanctioning the loan and to respond the quarries of SHG members.

- It is observed that $17.89 \%$ (34) of SHGs were faced the problem of administrating the affairs of its business. It is suggested that suitable administrative training to all the members of SHGs should be given or at least the animators and representatives of the groups may be given administrative training initially, then the same may be given to the members gradually. Further, Extension participation programme may be arranged with extension agencies for the SHGs to visit their business houses to know the functions and its administration. And also this extension participation programme will create awareness and skills of the business.

- It is also observed that 22 sample (11.57\%) SHGs were faced the problem of in adequate loan amount. Loan amount is one of the basic components to start an activity and also women can be financially sound when loan amount is given sufficiently. Loan amount should be increased to the extent that they can take up an income generating activity.

- Majority (92.45\%) of the members said that they could sign after joining the SHGs. Only $2.63 \%$ of the members are completed their XII standard. Education plays a crucial role in administering the affairs of the business. Hence, it is suggested that adult education system may also be adapted to the members of SHGs to upgrade their educational status.

- The development of a nation is vested on the shoulders of both men and women. Now a days the women self help groups are playing a predominant role in the eradication of poverty among the rural poor. It is suggested that the SHG concept for men is not adopted in the study area. If this has been implemented, the youth especially unemployed can be benefitted and they can also involve themselves in the process of poverty eradication. 


\section{Conclusion}

The new millennium has thrown many challenges subjecting many nations to undergo transformation cutting across their established tradition and culture. New issues have to be addressed to effect social and economical progress of our nation. The most important one is women's empowerment through Self-help groups. SHGs have undoubtedly begun to make a significant contribution in poverty alleviation and empowerment of poor, especially women in rural areas of our country. Women are the vital infrastructure and their empowerment would hasten the pace of social development. Investing in women's capabilities and empowering them to achieve their choices and oppturnities is the definite way to contribute to economic growth and overall development.

The empowerment of rural women leads to benefit not only to individual women and women groups, but also to the families and the community as a whole. The present study is an attempt to analyses the socioeconomic development of members and the performance of SHGs in this district. The performance of SHGs was good. The greater percentage of women were impacted positively by being members of SHGs. Women's participation in SHGs enabled them to discover inner strength, gain self confidence, social, economical, political and psychological empowerment and capacity building. If the aforesaid suggestions are carried out by the authorities concerned, the SHGs will improve in future.

[1] www.Silf Help Group.com

\section{Reference:}

[2] www.women empowerment.com

[3] Reports from mahalir thittam in perambalur district.

[4] Primary data from the SHG. 